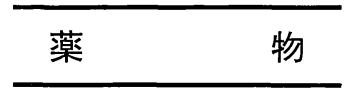

中枢性筋緊張弛緩剤 Muscalm のめまいに対する

治療効果；頭頸部外傷25症例における検討

$$
\begin{array}{ll}
\text { 中西和仁・桧 学 ・伊藤 信輔* } \\
\text { 多田 豊**. 安立 良治*** }
\end{array}
$$

\title{
Effects of Muscalm, a Centrally Acting Muscle Relaxant, on Vertigo and Disequilibrium of the Eyes and Body, Studies on Twenty Five Patients with Head and Neck Injury:
}

\author{
Kazuhito Nakanishi, Manabi Hinoki, Shinsuke Ito \\ (Kyoto Univ.) \\ Yutaka Tada \\ (Tokushima Municipal Hosp.) \\ Yoshiharu Adachi \\ (Kyoto Rosai Clinic)
}

Twenty-five patients who had suffered from pain of both the neck and waist and had tended to develop vertigo and disequilibrium of the eyes and body due to overexcitment of the proprioceptors of these regions were treated with Muscalm, a centrally acting muscle relaxant.

The results obtained were as follows: 1) This drug had a beneficial effect on some symptoms due to head and neck injury. It was more effective in treatment of vomiting, pain of the neck, stiffness of the neck and shoulder, vertigo, tremor of the four limbs, headache and pain of the waist. 2) There was a positive correlation between the improvement of vertigo and that of disequilibrium of the eyes and body. Furthermore, there was also a positive correlation between changes of the pain of the neck and waist and those of vertigo and disequilibrium of the eyes and body.

From these findings, it can be postulated that when Muscalm normalizes the overexcitment of $\gamma$ fibers involved in the proprioceptors in the neck and waist, hyperexcitability of the proprioceptors described above is first improved, and moreover, abnormal excitment of the equilibrium centers such as the hypothalamus, brain stem and cerebellum through the abnormal centripetal impulses from the proprioceptors is subsequently improved, As a result, the vertigo is relieved.

\footnotetext{
*京都大学医学部耳鼻咽喉科学教室（主任：桧学教授）

**徳島市民病院耳鼻咽喉科

***京都労災診療所
} 


\section{は じめに}

桧らは頭頸部外傷によるめまい例では，一方では頸部または腰部深部受容器などの末梢機構に活 動性亢進が存し，他方では脳幹，小脳など身体の平衡に関連の深い中枢機構に機能異常が存在する こと，並びに両者を結ぶ神経回路は徳循環系に転化し，両者が互いに「まと」と「引き金」の関係 をなして，めまい・平衡失調を惹起し，かつそれを持続，強化することを明らかにしてきた（桧， 他1967, Hinoki et al. 1971, Hinoki et al. 1973).

この考えを踏襲すると，乙の種めまいの治療の要点は，両者の機構の双方または一方の機能異常 を是正し，両者間に形成されている悪循環を遮断することにあると考える．乙れまでの報告を参照 すると，上述の末梢機構の機能異常を改善するには，薬物療法（消炎鎮痛剂，筋弛緩剤，マイナー トランキライザーなど), collar 装着による頸部の固定, 有痛部へのキシロカイン（またはプロカ イン）注射，パラフィン湿布および低周波刺激（陰極側を有痛部におく）などの方法が効果的であ る(桧1969, 桧1976).乙れに対し, 中枢機構の機能異常を改善するには脳幹賦活剂 (CDP-choline など）の投与がすぐれていることが明かにされている（牛尾，他1970）。頸部（又は腰部）の疼痛 に対する治療についてはな招究の余地が少なくない，例えば，有痛部へのプロカインブロックは 有効性が高いが，その手技は必ずしも簡便でない，また，乙の薬剤にアレルギー性反応を示す患者 が少なくない。:低周波刺激やパラフィン湿布は設備を要し，必ずしあ簡便とはいえない。従って， 薬物による疼痛の除去, ひいてはその部の梁部受容器活動性の正常化がのぞまれる.

以上の理由から，私達は頸部や腰部の愁訴（疼痛）に対して強力な鎮痛作用を有し，ひいては頸 部や腰部深部受容器起源のめまい・平衡失調をむ軽減する作用を有する薬剤で， かつ長期にわたる 服用でも副作用を示し難い薬物を究明中であった，その途上，次の筋弛緩剤に遭遇した。すなわち， Muscalm (2, 4'-dimethyl-3-piperidinopropiophenone hydrochloride) がそれである.ての薬 剂は, Nádor らにより発見され, Pósrzász らにより始めて中枢性筋弛緩剂として有効であるてと が報告された (Nádor et al. 1956, Pórszász et al. 1956). その後, 本剂の中枢性筋弛緩作用とし ての薬理効果は多くの基礎的および臨床的評価が行われ, その有効性が確認されている. てれまで の報告を参照すると，本薬剂は錐体外路系障害による筋強剛，錐体路系障害による筋攣縮及び頸肩 腕症候群，腰痛症などでおこる筋緊張充進を有効に抑制するてとが判明している．しかし，本薬剂 が頭頸部外傷例の疼痛抑制及びそれに由来するめまい. 平衡失調に対して有効か否かは充分に検討 されていない。

今回の報告では，問診及び平衡機能検査及び一般脳神経学的検査成績（とくに上肢小脳症状検查 成績）を基として，本薬剤の頭頸部外傷によるめまい．平衡失調に対する効果を論じてみたい。

成

(1)治療の対象

治療の対象は頭部外傷13症例，むちうち損傷 12 症例, 計 25 症例である.乙れらの症例の受傷 後の経過は 7 日〜 2 年 6 ケ月であり, 本剂投与 前に幾つか治療をうけているものは, このうち 20例である.

(2) Muscalm の投与法
績

1 日量 $300 \mathrm{mg}$ （症例によっては $150 \mathrm{mg}$ ）を 3 回 に分けて経口投与した. 投与は連日行ない, 詳 細に問診を行ないながら経過を観察し，原則と して 1 ケ月に 1 回, 以下のべる平衡機能検査及 び一般脳神経学的検查 (とくに上肢小脳症状検 查）を行った。な拉，頸部や腰部の痛み及びめ まいが改善し, 平衡機能検查や上肢小脳症状が 
好転する場合はその時点で投与を中止した。 ま た，ての薬剂を 1 ケ月に亘って投与して愁訴や 平衡機能検査成績や上肢小脳症状に有意の改善 がない場合，あるいは愁訴の増強を来たしたり， 平衡機能検査成績の増悪がみられた場合には， その時点で投与を中止した。

Muscalm の投与期間は，最低25日，最高 8 ケ月であった．本剤の投与期間中には，他の薬 物療法（例えば CDP-choline, ビタミン剂, 脳循環改善剂)，頸牽引，頸部低周波刺激，頸 部，腰部ブロック注射などは行っていない。

(3)調查項目

(i ) 愁訴の調査 (問診)

この報告では，頭頸部外傷による頸部，腰部 痛や「めまい」に対する Muscalm の効果をの べるととが主なる目的である，従って，てれら 愁訴の変動をその経過に従って詳細に記載する ことはあちろん大切である。しかし，乙の薬剤 が同時に存する他の愁訴に対しても有効な影響 をおよぼすととが判ったととと，他の愁訴に対 する本剂の効果を同時に調べるととは，頸部， 腰部痛や「めまい」に対するこの薬剂の効果を 更に浮彫りにするてとになると考えたので，以 下の10項目の愁訴をえらび，その変動を詳しく 問診した，愁訴の変化については，愁訴の消失 を一で表示し，愁訴の出現を+で表示すること にした。また，愁訴の軽快はH $H \rightarrow H の$ 如く表示し，その増悪は十 $\rightarrow$ Hまたは 世如く表示することにした.

(ii) 用いた平衡機能検査法と一般神経学的 検査

立直り反射検查（両脚直立, Mann's test, 単脚直立), 偏倚検査 (特発ならびに頭位眼振 検査, 遮眼書字検查, 足踏検査), 実験的眼振 検査（温度性眼振検査, 回転後眼振検査）の他 に，視運動眼振検査，アドレナリン負荷による 平衡試験（遮眼書字法）を行なった。また，一 般神経学的検查，とくに上肢小脳症状検查を同 時に行っている．てのうち，ての薬剤投与によ る小脳症状の変動に関しては次の規準を設けて
判定した，すなわち，指々，指鼻試験では 5 回 の trial 中 3 回以上 error を示すむのを異常 としたが，本剤投与でそのうち 2 回以上 error が変動（改善または増大）する場合を有意の変 動とした。また，上肢変換運動試験は肉眼的に 明瞭に変化したと思われる場合，乙の薬剤の効 果があらわれたと解釈した。

(4)得られた成績

(a)代表症例に扣ける観察

上述の 25 症例についての総括的成績を述べる に先だち，代表例を選んでその成績を詳述した い.

症例 S.A.45才, 우

昭和52年11月 16 日，停車中追突をうけた。 こ の際，意識混濁はなく，頭部打撲の自覚むな い. 事故直後加ら某整形外科に入院し, 頸部率 引療法，頸部マッサージ，薬物療法を受けた。 しかし，乙れら治療法は奏効せず，「めまい」 （回転感及び宙にういた感じ）, 頭痛, 頸部痛, 肩こり，腰部痛，悪心，呕吐などが持続してい る. 当科に入院後の諸検査の成績は以下の通り である．すなわち，血液及び尿などの一般的検 査成績, 肝機能, 血清蛋白, 心電図, 胸部レン トゲン検査，脳波検査成績はいずれも正常，ワ ッセルマン反応は陰性であった。

本例の Muscalm（300mg $\times 60$ 日間）投与によ る各愁訴の変化を表 1 に示してある，表示する ように，本剤の投与は各愁訴に対して有効に作 用している，すなわち，頭痛，めまい，頸部痛， 肩こり, 腰部痛, 悪心, 呕吐, 睡眠障害がおの おの消失している.

以下, この例の平衡機能検査の成績の推移を 申し述べたい，(1)立直り反射検査；Muscalm 投与前，両脚直立検査は正常所見を示したが， Mann's test では開眼時にも直立不能であっ た. Muscalm の投与後には, Mann's test 開 閉眼時にともに直立可能となった。 (2)自発なら びに頭位眼振検査；Muscalm 投与前には左に 向う水平性の自発眼振と方向固定型頭位眼振 （左へ向う眼振）をみとめた。本剂の投与によ 
表 I Muscalm 投与の治療効果（愁訴の変動に よる判定）

\begin{tabular}{|c|c|c|}
\hline 愁訴 & 投与前 & $\begin{array}{l}\text { Muscalm }(300 \mathrm{mg}) \\
60 \text { 日間投与後 }\end{array}$ \\
\hline 頭 痛 & $H$ & - \\
\hline 頭重感 & - & - \\
\hline めまい & $H$ & 一 \\
\hline 頸部・項部痛 & $H$ & - \\
\hline 頸部及び肩凝り & H & - \\
\hline 䁏部痛 & $H$ & - \\
\hline 悪心, 呕吐 & $H$ & - \\
\hline 四肢の振戦 & - & - \\
\hline 四肢のしびれ感 & - & - \\
\hline 睡眠障害 & + & - \\
\hline
\end{tabular}

りこれらの眼振は何れも消失した。 (3)遮眼書字 検査; Muscalm 投与前に軽度の右偏書が認め られ，本剤を投与しても有意の変動はなかっ た. (4)足踏検查; Muscalm 投与前には足踏検 查で後方への失調歩行が認められた. 本剂の投 与によりとの後方への失調歩行は消失した. (5) 実験的眼振検查; Muscalm 投与前の回転後眼 振検查（Bárány 法）は右廻し113打/60秒，左 廻し125打/63秒で, hyper-afternystagmus を 示し，温度眼振検査は正常值を示した．Muscalm 投与後には温度眼振検査の成績には有意
の変動なく, 回転後眼振は右迴し 29 打/38秒, 左廻し 30打/41 秒で正常值を示すようになっ た. (6)視運動眼振検査; 図 1 の上段に示したよ うに, Muscalm 投与前では, 光の縞の移動が 高速度になるにつれ，眼振の解発が不活発とな る. 本剤投与後では図 1 の下段に示してあるよ うに, 高速の光の縞の移動に応じて眼振の解発 は活発となっている，(7)アドレナリン負荷によ る平衡試験；アドレナリン投与前遮眼文字に軽 度の右偏書 $\left(7^{\circ}\right)$ がみられる.アドレナリンを 負荷すると右偏書は増大 $\left(15^{\circ}\right)$ し， かつ著明 な振戦が出現している（図 2 a), Muscalm の 投与により，頸部痛や「めまい」が消失した時 期では，遮眼文字には依然として右偏書 $\left(10^{\circ}\right)$ がみられるが，アドレナリンを負荷しても遮眼 文字に振戦はない（図 2 b).

表 2 亿は本例の平衡機能検查成績の変動を総 括的に示してある。本例の「めまい」改善は, 立直り検查, 偏倚検查抒よび回転後眼振検查及 び視運動眼振検査成績の正常化として客観化さ れている．また，振戦文字の出現が消失し，被 検者のアドレナリン耐性の向上がうかがわれ， これととあにめまいの改善がみられるようにな っていることが注目される。なお，本例では Muscalm 投与前の上肢小脳症状検査で，上肢

治療前

円筒左逜し $\left(1.0^{\circ} / \mathrm{sec}^{2}\right)$

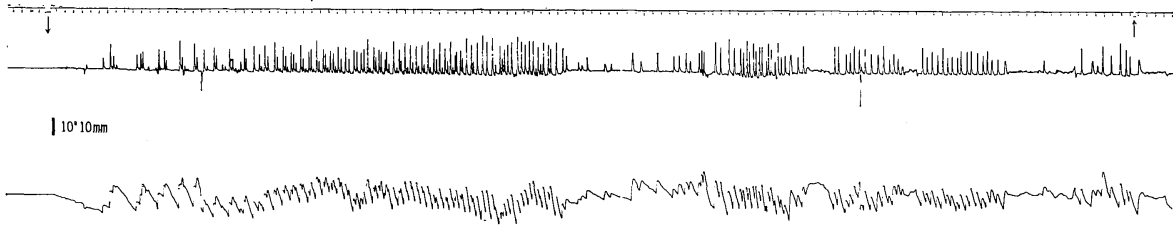

治療後 $300 \mathrm{mg} \times 60$ 日

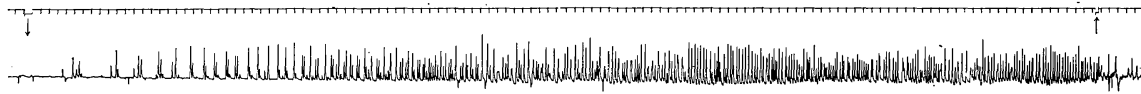

| $10^{\circ} 10 \mathrm{~mm}$

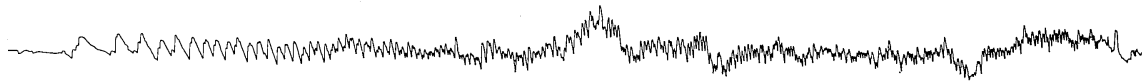
むちむち損傷，45才，우

図 I Muscalm 投与の治療効果 
$\begin{array}{ll}\text { 訂 正 } 72 \text { 巻 } 5 \text { 号 } & \text { P. } 657\end{array}$

\section{アドレナリン注射時の遮眼文字 \\ 治療後：300 mg × 60 日間}

注射前
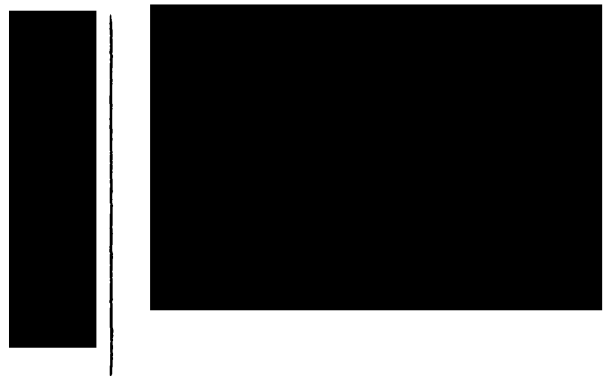

注射後10分
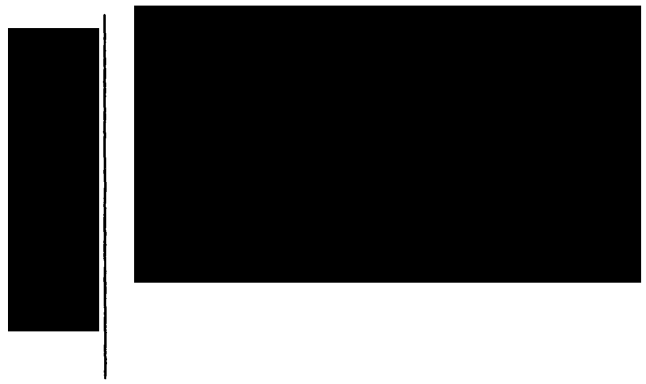

むちうち損傷，45才， 우

図 2 b Muscalm 投与の治療効果 
アドレナリン注射時の遮眼文字

治 療 前

注射前

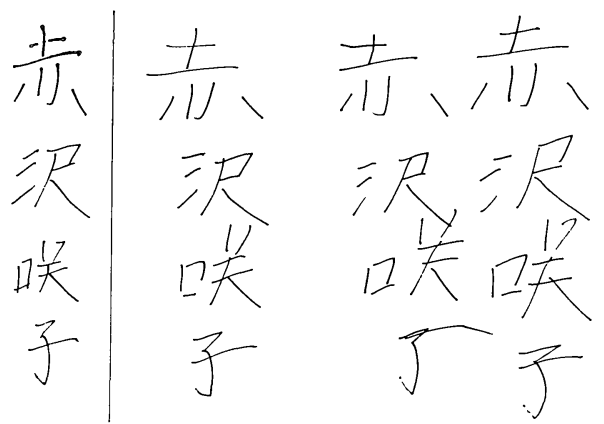

注射後10分

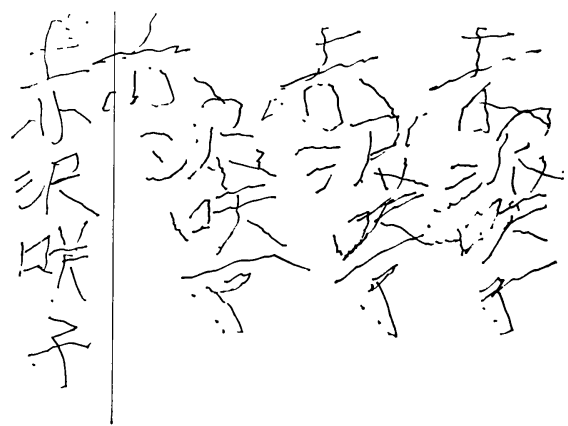

むちうち損傷, 45才, 우

図 2 a Muscalm 投与の治療効果
アドレナリン注射時の遮眼文字 治療後：300mg $\times 60$ 日間

注射前

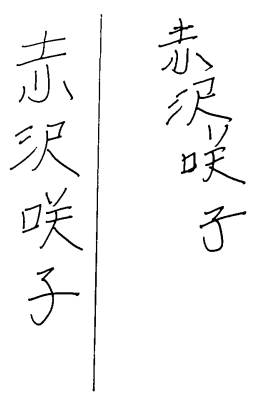

$\frac{ \pm}{10}$

口立

子

子

注射後10分

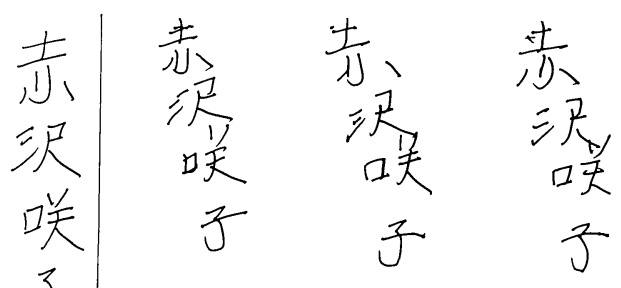

むちうち損傷, 45才, 우

図 2 b Muscalm 投与の治療効果

表 2 Muscalm 投与の治療効果 (平衡機能検査成績の変動による判定)

\begin{tabular}{|c|c|c|c|}
\hline \multicolumn{2}{|c|}{ 検査 $\quad$ 治療 } & 投 与 前 & $\begin{array}{c}\text { Muscalm } \\
60 \text { 日間投与後 }\end{array}$ \\
\hline \multicolumn{2}{|c|}{ 立直り検查 } & $H$ & - \\
\hline \multirow{3}{*}{$\begin{array}{l}\text { 偏 } \\
\text { 倚 } \\
\text { 検 } \\
\text { 査 }\end{array}$} & 自発又は頭位眼振検査 & 規則型頭位眼振 & 一 \\
\hline & 遮眼書字検查 & 右偏書 $\left(7^{\circ}\right)$ & 右偏書 $\left(10^{\circ}\right)$ \\
\hline & 足踏検査（正頭位法） & 後方失調歩行 & 常 \\
\hline \multirow{3}{*}{$\begin{array}{l}\text { 実検 } \\
\text { 験査 } \\
\text { 的 } \\
\text { 眼 } \\
\text { 振 }\end{array}$} & $\begin{array}{c}\text { 回転後眼振検查 } \\
\text { (Bárăny法) }\end{array}$ & $\begin{array}{l}\text { 右廻し } 113 / 60^{\prime \prime} \\
\text { 左廻し125/63" }\end{array}$ & $\begin{array}{l}\text { 右廻し } 29 / 38^{\prime \prime} \\
\text { 左廻し } 30 / 41^{\prime \prime}\end{array}$ \\
\hline & 温度眼振検査 & 正常 & 正 \\
\hline & 視運動眼振検査 & 眼振解発不活発 & 正 \\
\hline \multicolumn{2}{|c|}{$\begin{array}{l}\text { アドレナリン負荷による平衡試験 } \\
\text { (遮眼書字法) }\end{array}$} & 右偏書及び振戦文字 & 振戦文字消失 \\
\hline
\end{tabular}


変換運動が拙劣であり，指々，指鼻試験では 5 回の trial 中何れも dismetria をみとめてい る.しかし，との薬剤を投与すると，上肢変換 運動でみた hypodiadochokinesis は軽快し， 指々，指鼻試験でみとめられた dismetriaは 消失した。

(b)頭頸部外傷 25 症例における観察

（i ）愁訴に対する治療効果；以上の代表症 例をむふくめて 25 症例の頭頸部外傷例について 本剂使用による愁訴の変動を表 3 亿示した。，四 肢のしびれ感以外の愁訴に対しては何れにも本 剂は有効に作用している。すなわち，悪心，呕 吐18例中15例 (83.3\%)，頸部・項部痛23例中 18例 (78.3\%), 頭重感17例中12例 (70.6\%), 頸部及び肩凝り 22 例中15例（68.2\%），めまい 25 例中17例 $(68.0 \%)$ ，四肢の振戦 8 例 中 5 例

$(62.5 \%)$, 頭痛 21 例中13例 $(61.9 \%)$, 腰部痛 7 例中4例 $(57.1 \%)$, 睡眠障害 9 例中 5 例（55 .6\%) 飞奏効している.

以上のように，との薬剤は頭頸部外傷の愁訴 改善に有効であることが多い.

因みに，乙の薬剤の副作用として, 胸内苦悶, 呼吸障害, 倦点感, 脱力感, 食欲不振, 下淑な ごがあげられている，私達の症例では脱力感を 訴えたものが 1 例みられた。

（ii）平衡失調に対する治療効果；表 4 にそ
表 3 Muscalm 投与の治療効果 （愁訴の変動による判定）

\begin{tabular}{|c|c|c|c|c|}
\hline 治療 & 改善 & 不変 & 悪化 & 治療前に \\
\hline 頭 痛 & 13 & 8 & 0 & 4 \\
\hline 頭重感 & 12 & 5 & 0 & 8 \\
\hline めまい & 17 & 8 & 0 & 0 \\
\hline 頸部・項部痛 & 18 & 5 & 0 & 2 \\
\hline 頸部及び肩凝り & 15 & 7 & 0 & 3 \\
\hline 腰部痛 & 4 & 3 & 0 & 18 \\
\hline 悪心, 呕吐 & 15 & 3 & 0 & 7 \\
\hline 四肢の振戦 & 5 & 3 & 0 & 17 \\
\hline 四肢のしびれ感 & 3 & 5 & 0 & 17 \\
\hline 睡眠障害 & 5 & 4 & 0 & 16 \\
\hline
\end{tabular}

の成績の総括を示してある．表示するように， 多くの検查項目で Muscalm は平衡失調の改善 に有効に作用している，特に，立直り反射検 查，上肢，下肢の偏倚検查，視運動眼振や回転 後眼振検查で平衡失調の改善を示す傾向が明瞭 である．すなわち，足踏検査18例中13例（72.2 $\%)$, 遮眼書字検查 18 例中 12 例 $(66.7 \%)$, 視運 動眼振検查 22 例中 14 例 (63.6\%)，回転後眼振 検査13例中 8 例 $(61.5 \%)$, 立直り検查 23 例中 14例 $(60.1 \%)$ ，温度眼振検査 10 例中 6 例 (60.0 \%) が改善を示している，なお，自発又は頭位 眼振検査 14 例中 8 例 $(57.1 \%)$ ， アドレナリン

表 4 Muscalm 投与の治療効果

(平衡機能検查成績の変動による判定)

\begin{tabular}{|c|c|c|c|c|}
\hline 検 查 効 果 & 改善 & 不変 & 悪 化 & 治療前に異常なし \\
\hline 立直り検査 & 14 & 9 & 0 & 2 \\
\hline 自発又は頭位眼振検查 & 8 & 6 & 0 & 11 \\
\hline 遮眼書字検査 & 12 & 6 & 1 & 6 \\
\hline 足踏検查 & 13 & 5 & 1 & 6 \\
\hline 回転後眼振検査 (Báràny 法) & 8 & 5 & 1 & 11 \\
\hline 温度眼振検査 & 6 & 4 & 0 & 15 \\
\hline 視運動眼振検査 & 14 & 8 & 0 & 3 \\
\hline アドレナリン負荷による平衡試験 & 9 & 7 & 0 & 9 \\
\hline
\end{tabular}


負荷による平衡試験16例中 9 例（56.3\%）に改 善がみられる。

(iii) 頸部・腰部痛之めまい. 平衡失調の変 動の相関; 表 5 には本薬剂投与による頸部・腰 部痛とめまい愁訴の変動の相関を一括してあ る. 表示するように, 頸部・腰部痛の変動之 「めまい」愁訴の変動のあいだには正相関がみ られる.表 6 亿は本薬剂投与による頸部・腰部 痛の変動之平衡機能検査成績のそれの相関を一 括してある，表示するように，頸部・腰部痛の 愁訴の変動と平衡機能検査成績のあいだにも正 相関がみとめられる.なお, 表 6 でいう平衡機 能検查成績の変動の評価については次の基準に より行った. すなわち, 上述の 8 項目の平衡機 能検査のうち 3 項目以上の検査成績が変動する 場合を有意の変動とみなし，それ以外の場合を 不変とみなした，前者の場合，それらの成績が 好転する場合を改善，それらが増悪する場合を 悪化とみなした。

以上の一連の成績より, Muscalm は頭頸部 外傷例の頸部及び腰部の愁訴（疼痛；その部の 深部受容器の活動性方進）の是正に有効に作用 するばかりでなく，めまい・平衡失調の改善に も効果が高いととを結論できる.

（iv）上肢小脳症状検査成績を指標とする観 察；25症例の上肢小脳症状の検査成績の内訳を みると，指々試験で小脳症状を示したものは 25 例中 9 例 $(36.0 \%)$ ，指鼻試験でそれを示した 屯のは25例中 7 例 $(28.0 \%)$ ，上肢変換運動試 験ではそれが25例中 6 例 $(24.0 \%)$ であった。

また，以上の試験の何れかで小脳症状を示した あのは25例中11例（44.0\%）であった。 ての11 症例では Muscalm の投与で次の成績が得られ た。すなわち，指々試験で小脳症状の改善がみ られたものは 9 例中 4 例 $(44.4 \%)$ ，指鼻試験 でそれがおてったものは 7 例中 3 例 $(42.9 \%)$ である.そして，上肢変換運動試験ではそれが
表 5 頸・腰部痛とめまい愁訴の変動の相関

\begin{tabular}{c|c|c|c}
\hline 頸・腰部痛 & 改 善 & 不 変 & 悪 化 \\
\hline 改 善 & 16 & 2 & 0 \\
\hline 不 変 & 1 & 6 & 0 \\
\hline 悪 化 & 0 & 0 & 0
\end{tabular}

表 6 頸・腰部痛と平衡機能検査成績の変動の相関

\begin{tabular}{c|c|c|c}
\hline \hline $\begin{array}{r}\text { 平衡機能 } \\
\text { 頸・腰部痛 }\end{array}$ & 改 善 & 不 変 & 悪 北 \\
\hline 改 善 & 15 & 3 & 0 \\
\hline 不 変 & 0 & 7 & 0 \\
\hline 悪 化 & 0 & 0 & 0
\end{tabular}

6 例中 2 例 $(33.3 \%)$ であった. なお，以上の 試験のうちいずれか一項目に括いてであ小脳症 状の改善を示したものは11例中 5 例 (45.5\%) であった．本剂投与前上肢小脳症状を示さなか った25例中14例では投与後に括いて小脳症状の 出現を示したものはなかった。

因みに，Muscalm 投与による頸部・腰部痛 と小脳症状の変動の相関について調査すると次 の事実が判った（の頸部・腰部痛の双方または 一方のいずれかの愁訴が改善された 7 例中 5 例 (71.4\%) は小脳症状が改善し，2 例 (28.6\%) では有意の変動がなかった。回頸部・腰部の愁 訴に有意の変動がなかった 4 例は全例小脳症状 にも有意の変化をみていない.

以上の一連の成績からみると, この薬剤は頸 部・腰部の深部受容器の活動性亢進を抑制し, ひいては小脳の機能異常を是正する作用を有す るむのと考えられた。 


\section{総括 と考按}

Muscalm の作用機序に関しててれまでの報 告を参照すると, 大略次の様に要約される.

(1)中脳網様体加らの下行性 $\gamma$ 系路の活動性抑制 (福田1973 a , 藤井, 他 in press), (2)筋紡錐 発射の抑制（福田 $1973 \mathrm{~b}$ )，(3)脊骾の多シナプ ス反射，単シナプス反射の抑制 (Kato et al. 1965, 福田 1973b)， (4) $\alpha$ 細胞の興奮性抑制 (Černáček 1966) などである.すなわち，本 薬剂は $\alpha$ 系及び $\gamma$ 系を介する筋緊張穴進に対し ても抑制的作用を有する中枢性筋弛緩剂と考え られている。

従って, この薬剂は錐体路疾患, 錐体外路疾 患, 頸肩腕症候群, 腰痛症などに広く応用され ている、しかしながら，てれまでに頭・頸部外 傷による頸部・腰部痛や「めまい」に対する本 薬剤の有効性について, 神経耳科の立場から系 統的に分析し，報告されたものをみない.

以下得られた成績について私見を述べてみた い.

(A)頸部・腰部痛に対する治療効果 ; 表 3 亿示 したように，頸部痛の改善したものは23例中18 例 $(78.3 \%)$ であり, 腰部痛の改善したものは 7 例中 4 例 $(57.1 \%)$ である.とのととは，乙 の薬剂が頭頸部外傷による頸部・腰部痛に有効 性が高いととを示唆している，乙の様な成績が 得られたのは，本薬剂が骨格筋の緊張をつかさ ぞる筋紡錐やそれを支配する $\gamma$ 系の活動性に対 し抑制的に作用した結果，頸部または腰部脊柱 起立筋の緊張六進が是正されたためであろう. なお，乙の項目で次の点を指摘しておきたい. 上述したように，アドレナリン投与による失調 文字 (振戦文字) は Muscalm 投与後, 頸部又 は腰部痛の改善と正相関して消失する傾向があ る.

川村，大島（1962）らによると，アドレナリ ンの中枢機序としては後部視床下部に直接作用 し，それを介して大脳辺縁系（海馬，扁桃核） の活動性え進を惹起するという。そして，上記
の辺縁系, 例えば海馬が骨格筋緊張と密接な関 連を有することはこれまでにあ報告がある（安 原1972). 一方, Bowmann, Raper (1967) の 基礎的実験や桧，仁木らのむち打ち損傷例を対 象とする臨床的検索よりすると，アドレナリン は $\beta$ stimulant としての作用を有し，損傷を うけた骨格筋の緊張え進に有意の役割を果すと とが判明している (Hinoki, Niki 1975). 従っ て, Muscalm 投与による頸部・腰部痛の改善 は, 従来報告されているての薬剤の $r$ 系への作 用のみでなく，筋緊張方進之関連する交感神経 系への作用をむ考慮すべきものと思う。乙の考 えが妥当か否かの究明は，今後にのこされた問 題点と考えるので，ここに私見をのべた.

(B)めまい・平衡失調に対する治療効果 : 平衡 機能検查成績加らみた考察; 表 3 , 表 4 亿示し たように，めまいの改善（消失または軽減）を 示したものは25例中17例 $(68.0 \%)$ である。 そ して, それらの症例について平衡機能検査を行 ってみると, 各種の検査, とくに立直り検査, 上肢, 下肢の偏倚検査, 回転後眼振検査及び視 運動眼振検査でみとめられた眼球及び躯幹, 四 肢の平衡失調がかなりの率（それぞれ60\%以上 の改善率）で改善を示している. このことは, この薬剤が頭頸部外傷によるめまいにも有効性 が高いことを示唆している. それでは, どの様 な機転でこの様な成績が得られたのであろう か?

その一つの機序はこの薬剤が眼球，躯幹，四 肢の平衡中枢に直接的作用を有し, その部の機 能異常を正したとする仮定である．他は，乙の 薬剤が $\gamma$ 系（あるいは上述したように交感神経 系を介するかむしれないが）を介して頸部・腰 部深部受容器の活動性え進を抑制し, それに由 来して平衡中枢と頸部又は腰部深部受容器の間 の悪循環が正され, 平衡失調の改善, めまいの 寛解があたらされたとの考えである，前者につ いての系統的実験は未だ充分でないとしても， 
後者の機序については桧らにより幾つかの実験 的又は臨床的資料がある (Hinoki et al. 1971 Hinoki et al. 1973，桧1976). その何れの機序 が優位をしめるかはなお今後の検討をまつ他は ないが，後者の機序がこの薬剤のめまい・平衡 失調の改善の背景をなすとの考えには大きなま ちがいはないものと思う。

なお，この項目でとの楽剂投与による視運動 眼振之回転後眼振の変動について申しのべてお きたい，周知のように，視運動眼振は視器のも つ平衡機能の表示と考えてよい. これに対し, 回転後眼振は強烈な迷路刺激でおてる眼球の平 衡障害と考えてよい. 從って, めまい. 平衡失 調を改善する薬剤としては前者の眼振の解発を 促進し，後者のそれを抑制する作用を有すると とがのぞましい.

桧ら（1967）はこの様な作用を有する薬物と して脳幹賦活剂（Lucidril）をあげている。 そ して，今回の検索で Muscalm にもその様な作 用機序の存することが判明した。勿論, 前者の 楽剤の場合は，その作用機序から考え，乙の薬 剂によるより直接的な脳幹平衡中枢の機能の改 善がその責任をおうべきあのと考える．乙れに 対し，後者の場合は，その作用機序から考え， 先づ頸部・腰部深部受容器の活動性亢進が是正 され，乙れに応じて二次的に脳幹又は小脳の機 能改善があたらされ，かくして上述の視運動眼 振之回転後眼振の特徵的変動があたらされたあ のと理解すべきであろう.

(C)小脳の機能異常と関連した本剂の有用性 : 上肢小脳症状検査成績を指標とする考察；乙こ でこの薬椷投与による上肢小脳症状検査成績の 変動について私見を述べて拈きたい，上述した ように，乙の薬剂の投与で上肢小脳症状を示し た11例中 5 例 (45.5\%) はその症状が寛解して いる. この成績の解釈には次の 3 つが考えられ る. (1)との薬剤が小脳に作用してその機能異常 を正した，@との薬剤が頸部又は腰部梁部受容 器活動性㐫進を是正し，ひいてはそれと深い関 連のある小脳の機能異常を正した, ○(1), (口)
機序が同時に成立した．その何れが正しい理解 であるのか，ただ今のところ決定的な答は出し 得ない。しかし，てれまでの報告を参照すると， (口の機序がこの成績をむたらしたと考えること は不当ではないと思う．乙の考えは，(1)ての薬 剂の投与で頸部・腰部の双方又は何れか一方の 愁訴を改善した 7 例中 5 例 $(71.4 \%)$ では同時 に存した上肢小脳症状が改善し，てれらの部位 の愁訴に有意の変化がなかった 4 例では，何れ 屯上肢小脳症状に明瞭な変化はおこっていな い, 回頸部, 腰部は, 小脳, とくにその虫部之 それぞれ cuneocerebellar tract, posterior spinocerebellar tract などをむって密接に連 絡し, 前者の機能の変化は後者に有意の影響を 与えうる，牛尾らが行った頸部・腰部，之く に後者の有痛部への procaine 注射による上肢 小脳症状の変動と Muscalm 投与のそれの間に 相似性をみとめる，などの事実よりも納得でき ると思う。

さて，小脳に機能異常が存する場合，頭頸部 外傷によるめまいは遷延化が著しい（牛尾ら 1975，桧 1972，日根 1975）。 そして，てのよう な例で上肢小脳症状を有効にコントロールする 方法としては，牛尾らがのべた腰部有痛部への procaine 注射がみられるのみである。この 点, 今回の検索で, Muscalm が頸部又は腰部 深部受容器活動性の是正を媒介として小脳の機 能障害に対して有意の影響を与えうることを明 玑しえたてとは注目してよい，とくに，ての 薬剤が小脳症状の悪化をむたらすととなく，ま た procaine 注射に比し, その操作が簡便であ るととはその利点というべきであろう.

(D)その他の愁訴，特に自律神経症状に対する 治療効果; 自律神経症状, 例えば悪心, 呕吐に 対しても Muscalm は有効に作用し，18例中15 例 (83.3\%) 飞改善をみている。 そして, 自律 神経症状の変動之頸部又は腰部痛のそれの間に は次の関係がみられた。すなわち, 頸部又は腰 部痛の寛解をみた16例では自律神経症状であ 15 例にそれがみられ，頸部又は腰部の愁訴に有意 
の変化がなかった 5 例では自律神経症状にあ有 意の変化をみていない，すなわち，両者の間に 正相関がうかがわれた。このととは，乙の薬剤 投与による自律神経症状の变動は深部受容器— 自律神経反射の変化として理解すべきととを示 唆している．桧は樑部受容器起源の反射には眼 反射, 脊䯣反射の他に自律神経反射が存し, 頭 頸部外傷にみる自律神経症状はこの反射の異常 に由来するあのが少くないととを明らかにして いる(桧1976). そして, 深部受容器系と自律神 経 (交感神経) 系に関する連絡路に関して次の 考えをのべている，すなわち，頸部または腰部 深部受容器からの上行性インパルスは spinoreticular tract を経て, 脳幹網様体に達する ばかりでなく，中脳中心灰白質に達し，次いで tegmentohypothalamic tract を介するかま たはこれを介することなく視床下部に終止する ルートがある。また，視床下部からの遠心性交 感神経路としては Schütz 氏背側縦束があり， この遠心性自律神経路は脊䯣側角に入り，つい で頸部または腰部交感神経索を介し，その節後 線維が交感神経支配下の各種臓器に分布してい
る. 従って，頭頸部外傷例にみられる各種の自 律神経症状を改善するには，頸部または腰部 (特に前者) の有痛部にキシロカイン（または プロカイン）を行う方法は有効であるはづであ る，そして，すでにその考えの妥当性が確かめ られている（松浦1976）。 さて，上述した $\mathrm{Mu}-$ scalm の作用機序よりすると，本剤の投与によ り頸部または腰部深部受容器よりの異常なイン パルスが遮断されるととになり，その結果深部 受容器起源の自律神経反射異常が是正され, 上 記の愁訴の改善があたらされたものと想定され る. そして，乙の考えを支持するのは，Muscalm の投与により16例中 9 例 $(56.3 \%)$ にア ドレナリン負荷による平衡試験の成績が陰性化 している事実であろう。因みに，アドレナリン は後部視床下部に直接作用し, 大脳辺縁系の活 動性を activate し，他方では中脳被蓋に作用 してその脳の活動性を六進することがしられて いる (Kawamura, Oshima 1962, Rothballer 1956). これらの脳が，自律神経系とも梁い関 連を有することは解剖学及び生理学の研究によ りすでに系統的に証明されている.

\section{むす び}

頭頸部外傷例の中で，頸部または腰部痛を有し，てれがめまい・平衡失調の原因をなしていると 考えられる症例に, Muscalm を投与し，次の事実を知った. (1) Muscalm は四肢のしびれ感をの ぞいて種々の愁訴に有効に作用することがわかった，その中でも，恶心，呕吐，頸部・項部痛，頭 重感，頸部及び肩凝り，めまい，四肢の振戦，頭痛，腰部痛などの愁訴には有効であった。なお， めまい愁訴の好転は平衡機能異常の改善と大略平行した。 (2) 頸部・腰部痛とめまい・平衡失調の変 動のあいだには正相関がみられた。

この成績を基として，次の考えを述べた，頭頸部外傷例にみられる各愁訴，とくにめまい・平衡 失調や自律神経症状に対して本薬剂が有効に作用するのは, (1)本薬剤が頸部・腰部梁部受容器と関 係のある $r$ 系の活動性を是正し, その部の深部受容器の活動性亢進が正常化する. (2)くして, こ れに対応する中枢機構（視床下部，脳幹，小脳）の機能の改善がもたらされた故と考えられる.

\section{参 考 文 献}

1) Bowman, W. C., and Raper, C. : Adenotropic receptor in skeletal muscle. Ann. New York Acad. Sci. 741:139, 1967.

2) Černáček, J. \& Jágr, J.: The evaluation of the antispastic activity of a myordaxant by means of electromyography. IV Conferentia Hungarica pro Therapia et Investigatione in Pharmacologia. 557, 1966. 
3 ) 藤井祐一, 他: Tolperisonehydrochloride の神 経薬理学的研究. 日薬理誌(in press)

4 ）福田英臣 : 徐脳固縮に対するムスカルムの作用. ムスカルム基礎臨床文献集，日本化薬，1973 a .

5 ) 福田英臣：中枢性筋弛緩薬 $2,4^{\prime}$-ジメチルー 3 ピペリジノプロピオフェノン（ムスカルム）に関 する薬理学的研究. ムスカルム基礎臨床文献集, 日本化薬, $1973 \mathrm{~b}$.

6) 日根其二 : めまい・平衡障害の予後診断, 神経耳 科検査の実際. 医学書院, 東京, 127, 1975.

7 ) 桧学, 他：頭頸部外傷における頸性めまい発現機 転に関する考察. 耳鼻臨床 $60: 14,1967$.

8 ）桧学, 他：頭部外傷後遺症に対するルシドリール 使用経験；特に大後頭神経ブロックによる治療効 果との比較観察. 耳鼻臨床 $60: 841,1967$.

9) 桧学：治療; 耳鼻咽喉科の立場加 , 外傷性頸部 症候群，いわゆるむち打ち損傷(諸富武文編), 南江堂, 東京, 1969 .

10) Hinoki M., Hine, S. and Tada, Y.: Neurotological studies on vertigo due to whiplash in jury. Equil. Res. (Suppl. 1) 1, 1971.

11）桧学：神経耳科からみたむち打ち損傷；むち打ち 症 (伊丹編), 新臨床文庫 100 , 金原出版, 東京, 104 105, 1972.

12) Hinoki, M., Hine, S., Ushio, N. Ishida, Y. and Koike, S. : Studies on ataxia of lumbar origin in cases of vertigo due to whiplash injury. Equil. Res. 3 : 141, 1973.

13) Hinoki, M. and Niki, H.: Neurotological studies on the sympathetic nervous system in the formation of traumatic vertigo of cervical origin. Acta Otolaryngol. (Stockholm) Suppl. $330:$ 185, 1975.

14）桧学：Trigger-and-Target Relationship の考
えからみた頭頸部外傷によるめまい・平衡失調. 耳鼻臨床 $69: 1641,1976$.

15) Kato, M., Motokizawa, F., Fujimori, B. : Effects of 1-piperidino-2-methy1-3-(p-tolyl) propan-3-one upon spinal motor activities and EEG. J. Pharmacol. Exp. Ther. 149 : 131, 1965.

16) Kawamura, H. and Oshima, K. : Effect of adrenaline on the hypothalamic activating system. Jap. J. Physiol. 12:225, 1962.

17）松浦健次郎：平衡機能との関連からみた深部受容 器一自律神経反射. 耳鼻臨床 $69: 1391,1976$.

18) Nádor, K. u. Pórszáz, J,, Arzneim.-Forsch. $6: 696,1956$.

19) Pórszász, J. u. Nádor, K., Arzneim.-Forsch. $6: 695,1956$.

20) Rothballer, A. B. : Studies on the adrenaline sensitive component of the reticular activaating system. EEG Clin. Neurophysiol. 8 : 603, 1956.

21）牛尾信也，他：いわゆるむち打ち損傷による「め まい」に対する CDP-choline (Nicholin) の治 療効果・耳鼻臨床 $63: 985,1970$.

22）牛尾信也，他：頭頸部外傷による「めまい」，平 衡失調症例の予後に関する臨床的観察 ; 問診所 見，平衡機能検査成績を指標として．耳鼻臨床 $68: 1075,1975$.

23）安原基弘：神経薬理学からみた脳波の成因. 臨床 脳波 I4:148, 1972.

原稿到着：昭和 53 年 10 月 4 日
別刷請求先: 中西和仁
昰 606 京都市左京区聖護院川原町 53
京都大学医学部耳鼻咽喉科学教室

